УДК 376.011.3-051(71)

DOI: http://dx.doi.org/10.30970/vpe.2018.33.9980

\title{
INCLUSIVE COMPETENCE OF TEACHER ASSISTANT: CANADIAN EXPERIENCE
}

\author{
Bohdana Turko \\ Ivan Franko National University of Lviv, \\ Tuhan-Baranovskoho Str., 7, Lviv, Ukraine, UA-79005
}

The article reveals vital problem of inclusive competence development as integral personal-professional competence of teacher assistant. Teacher Assistant is a person cooperating with a teacher who participates in educational program implementation at primary school and pre-school institutions. Assistants work in public and private schools, educational centers, specializing educational institutions. Their main task is to help a teacher who works individually or with a group of students including students with special needs, realizing at the same time inclusive approach in educational process. The results of effective learning greatly depend on professional competence of teacher assistant. That is why future assistants have to gain skills of professional self-improvement, be ready and able to avoid professional burning during their lives, on the contrary reach professional mastery. Canadian achievements in the sphere of professional preparation of assistants to conduct inclusive learning became the basis of investigation. An important element in the system of preparation of teacher assistant in Canada is multicultural component as important component of professionalism.

Key words: teacher assistant, inclusive education, inclusive competence, children with special educational needs.

Taking into consideration integration tendencies of last decades inclusive education in social policies of most democratic countries of the world is determined not as separate component of social life but in wider context. The development of inclusive approach in educational process is considered by UNESCO, OSCE and other international organizations as priority direction of national school education system development, as realization of citizens' right to qualitative education is important factor sustainability of society.

Ukraine joining main international agreements in the sphere of civic rights takes responsibility for the observance of universal human rights, especially ensuring the right to education for children with special educational needs. One of the main tasks of National Strategy of Reformation of institutional care and upbringing of children for 2017-2026 is network development and provision of educational, medical, social, rehabilitation services (mainly early interference, inclusive learning) on the level of local community taking into account the needs of the inhabitants.

(C) Turko B., 2018 
The Law of Ukraine on Education from 05.09.2017 \# 2145-VIII determines the notion of inclusive learning as system of educational services guaranteed by the state based on the principles of nondiscrimination, considering diversity of people, effective insolvent and including all participants of the learning process.

There is political will concerning inclusive learning in Ukraine as well as sufficiently formed legislative base which is constantly improved. Inclusive learning organization should be guided by the decree of the Cabinet of Ministers of Ukraine from 15.08.2011 \#872 "Approval of the order of the organization of inclusive education in general educational institutions (with amendments in accordance with the resolution of the Cabinet of Ministers of Ukraine \#588 from 09.08.2017, which determines requirements to the organization of inclusive learning in general secondary educational institutions aiming to realize the right to education for children with atypical development by the place of residence, their socializing and integration into society, maximum engagement of parents in educational process.

We consider an important document to be The Decree from 12.072017 \# 545 About Approval of the Provision on the Inclusive Resource Center with the amendments introduced in accordance with the Resolution \#617 from 22.08.2018 where the government recommends creating inclusive resource centers. Such centers appeared in Ukraine for the first time. They provide school teachers' learning and specialists for advanced learning. Besides this institutions will perform analytical work. In this way they will determine how early interference influences the development of a child with special educational needs, better program to develop a child, etc. 25 inclusive resource centers are created in Lviv oblasts' providing educational needs for children with disabilities. Such centers provide children with special educational needs aged 2-18 with psychological pedagogical help while learning pre-school institutions and schools, and carry out a comprehensive assessment of child's development [6].

The Aim of our investigation is determine the phenomenon of inclusive competence of teacher assistant which determines the ability to solve professional tasks in the conditions of inclusive approach to educational activity in Canada.

A lot of Ukrainian and Canadian scientists researched the problem of inclusive learning accomplishment and teacher assistant preparation, formation of professional competence. Among them are A. Lapin, N. Kompanets, V. Synyov, D. Shulzhenko, N. Pahomova, N. Sofiy, O. Hloba, I. Lutsenko, H. Davydenko, I. Biletska, M. Voron, O. Koval, A. Kplupayeva, L. Kashuba, J. Deppeler, D. Harvey, J. Lupart, Ch. Webber.

In the conditions of European integration changes in Ukrainian educational system it is reasonable to pay attention to positive practical experience of foreign countries, particularly the experience of Canada considering Ukrainian national context. Preparation of pedagogical workers in Ukrainian educational institutions 
ISSN 2078-5526. Вісник Львівського університету. Серія педагогічна. 2018. Випуск 33

faces the challenge to reform the structure of professional competence considering the renewal of key professional competences of teacher assistant. Taking into account that a child with special needs should have the possibility of free choice of learning establishment, in any of which teacher assistant has to be highly professionally prepared, adjusted to the conditions of inclusive learning in order to help a teacher to conduct learning process.

Creative learning exactly, analysis and personal experience evaluation may help to overcome crisis phenomena existing in modern system of teacher assistant preparation in Ukraine, to enrich pedagogical science of Ukraine with new ideas and achievements. Such experience borrowing will promote higher level of effective preparation as well as positively effect the renovation of forms, methods, and ways of work with pedagogues to be which will consequently lead to successful integration of national education to European educational sphere.

According to the resources educational legislative acts in Canada guarantee relevant educational programs, resources providing to support students with special needs for them to participate in academic and civil school life. Introduction of additional pedagogical staff in learning institutions mainly teacher assistants is guaranteed government support for students with special needs [3, p. 158].

Teacher assistant is a person helping teacher to complete the training program in pre-school and secondary education institutions that is to realize inclusive approach in educational process.

Nowadays modern foreign and Ukrainian scientists working in the sphere of comparative analysis of educational integration or inclination realization (I. Biletska, M. Voron, O. Koval, A. Kolupayeva, D. Lupart) discovered socio-cultural conditions, common regularities and specific peculiarities of ideas of inclusive learning embodiment in pedagogical systems in different countries. It is indicated in most of the works of mentioned above scientists that the main precondition of educational integration and inclusive learning surrounding creation is high level formation of key professional competences of educators to work with diverse range of students in the conditions of mass school. In accordance we pay attention to the conception of integrated competence development of teacher assistants.

J. Lupart and Ch. Webber substantiate the provisions of that results of effective teaching greatly depend on professional competence of teacher assistant. That is why assistants-to-be have to gain skills of professional self-improvement and be ready to avoid professional burnout but to get pedagogical mastery [9, p. 1].

M. Chaykovskyy reveals the concept of inclusive competence as the level of skills and abilities necessary to perform professional functions in the conditions of professional learning involving teacher assistant. Professional competence of assistants includes skills and abilities from various spheres of vital activity of a person necessary to help in creating skills and abilities to do creative work. 
Specialist's competence development is connected with integration of intellectual, moral, social, aesthetic and political skills and abilities [7, p. 15].

According to A. Dzurynskyy policultural component is an important component of theoretical and practical professional preparation of future teacher assistants in the conditions of inclusive educational surrounding. Theoretical principles of policulture are important components of teacher assistant professionalism as the fulfillment of the tasks involves strengthening policultural component in teacher assistant preparation. Canadian researchers particularly pay attention to children with special needs emigrated from other countries. The process of inclusive learning takes into consideration development perspectives of certain forms of social behavior, individual likes and intentions of children with special educational needs belonging to various ethnic groups, having their socializing peculiarities in policultural learning surrounding of Canadian schools, which depicts social-economic changes of Canadian society [1, p. 79].

According to scientific researches of Canadian scientists priority directions of work are to facilitate social, emotional and cognitive development of a child in order to make them feel unique and valuable participants of social life. In such way inclusive education in Canada foresees the change of school administration attitude to learning process of special children, as only correctly directed and systematically conducted educational work will provide protection of quality education for every child especially a child with special educational needs [3, p. 129].

In his thorough research of the problem of inclusive learning A. Kumer emphasizes the importance of professional preparation of pedagogical staff to work in inclusive classes: "Pedagogical staff and school psychologist should be aware about a child's development, their actual and potential abilities, necessities and life orientations as pedagogues should be familiar with not only general knowledge about a child, but know the peculiarities in order to clarify whether the school surrounding is favourable for learning and development of a child and if not to find out the reason. If teachers and psychologists are not able to eliminate the cause, they have to level it. Knowing the child they have to modify school surrounding in such a way to make it the most favourable for realization of educational, development and up-bringing tasks. It is necessary to help the child to solve the problems appearing in interaction with the surrounding. The task of a teacher assistant in the process of pedagogical activity is to help to establish interaction of a child with development problems with other participants of educational process" [6].

The role of a pedagogue and teacher assistant in particular is to create peculiar mediation in subject-subjective relations in inclusive school practice. Inclusive learning requires high level of professionalism of every teacher assistant, reaching which promotes inclusive competence formation. 
1. Джуринский А. Н. Поликультурное воспитание в США и Канаде / А. Н. Джуринский // Мир образования - образование в мире. - 2002. - № 4. - С. 79-87.

2. Колупаєва А. А., Савчук Л. О. Діти з особливими освітніми потребами та організація їх навчання. Видання доповнене та перероблене: наук.-метод. посіб. / А.А. Колупаєва, Л.О. Савчук, Київ: Видавнича група «АТОПОЛ», 2011. - $274 \mathrm{c}$.

3. Луценко I. В. Правові аспекти запровадження інклюзивної освіти в Україні / І. В. Луценко. Інклюзивна освіта - освіта для усіх. - 2014. - С. 8-17.

4. Нос Л. С. Підготовка вчителів початкової школи в Канаді: теорія і практика: навч. посіб. / за ред. Н. Г. Ничкало. - Бадікова Н.О. - Л. - 2016. $300 \mathrm{c}$.

5. Чайковський $M . ~ \epsilon$. Інклюзивна компетентність як складова професійної компетентності суб'єктів навчально-виховного процесу / М.Є.Чайковський // Педагогіка і психологія професійної освіти: науковометодичний журнал. - 2012. - № 2. - С. 15-21.

6. Linda Allal, Moffier Lucie Lopez. Formative Assessment. Improving Learning in Secondary Classrooms. - OECD Centre for Educational Research and Innovation. - Paris: OECD Publishing, 2005. - P. 241-264.

7. Lupart J., Webber Ch. Canadian Schools in Transition: Moving from Dual Education Systems to Inclusive Schools. - [Електронний ресурс]: [Canada Ukraine Research Team]. - Режим доступу: http://www.canadaukraine.org/Articles.htm. 
ISSN 2078-5526. Вісник Львівського університету. Серія педагогічна. 2018. Випуск 33

\title{
ІНКЛЮЗИВНА КОМПЕТЕНТНІСТЬ АСИСТЕНТА ВЧИТЕЛЯ: КАНАДСЬКИЙ ДОСВІД
}

\section{Богданна Турко}

Львівський наџіональний університет імені Івана Франка, вул. Туган-Барановського, 7, Львів, Україна, 79005

\begin{abstract}
Розкрито актуальну проблему розвитку інклюзивної компетентності як інтегральної особисто-професійної компетентності асистента викладача. Проаналізовано проблему професійної підготовки викладача-помічника у співпраці з вчителем в інклюзивному класі. Проаналізовано наукові підходи до визначення змісту поняття професійної компетентності асистента, досліджено погляди вчених на зміст, основні структурні компоненти та сучасний рівень професійної компетентності викладача в Канаді та Україні. Також автор публікації розглядає необхідність формування професійної компетентності помічника вчителя інклюзивного класу, а саме, його глибоких знань у суміжних областях, вміння застосовувати їх до кожної конкретної дитини, виявляючи здібності учнів з особливими потребами, а отже задоволення їхніх освітніх потреб.

Асистент вчителя - це особа, що співпрацює з педагогом, який бере участь у впровадженні освітньої програми в початковій школі та дошкільних установах. Асистенти працюють у державних і приватних школах, навчальних центрах, спеціалізуються навчальні заклади. Їх основне завдання - допомогти викладачу, який працює індивідуально або з групою студентів, включаючи студентів 3 особливими потребами, реалізуючи при цьому інклюзивний підхід у навчальному процесі. Результати ефективного навчання значною мірою залежать від професійної компетентності асистента викладача. Тому майбутнім асистентам належить набути навички професійного самовдосконалення та самоаналізу, бути готовими і здатними уникнути професійного спалювання протягом свого життя, навпаки досягти професійного майстерності. Основою дослідження стали канадські досягнення у сфері професійної підготовки асистентів до проведення інклюзивного навчання. Важливим елементом системи підготовки асистента в Канаді є багатокультурний компонент як важлива складова професіоналізму.
\end{abstract}

Ключові слова: асистент вчителя, інклюзивна освіта, інклюзивна компетентність, діти з особливими освітніми потребами. 